\title{
Stuck Places and Possibilities: Questions of Culture, Collaboration, and Complexity in (Re)imaginging Teacher Preparation
}

\author{
WALTER GERSHON \\ Kent State University (USA)
}

In (Re)imagining Teacher Preparation for Conjoint Democratic Inquiry in Complex Classroom Ecologies coauthors Seltzer-Kelly, Cinnamon, Cunningham, Jones and Toth examine their respective educational experiences, setting them along side one another so they might examine emergent patterns in order to suggest ways in which teacher education might be reconceptualized. As an interpretive researcher in curriculum studies who has an interest in questions about the complex nature of methodology, collaboration, and sensemaking (e.g. Gershon, 2008, 2009), I was pleased to be asked to respond to their article.

Seltzer-Kelly et al. begin their article with the following statement: "Embracing a complexity-based model-particularly the Batesonian focus upon the interaction of systems-this work weaves together deeply qualitative and autoethnographic approaches with quantitative empirical studies and philosophic theorization" (p. 1). This statement is followed by a citation from Davis and Sumara (2006) about the ways in which complexity does not seek the singularity of meta-discourses but instead provides a means for noting "profound similarities across a diversity of phenomena" (p. 127). In sum, the coauthors claim complexity exists "not only in our thinking...but in our mode of inquiry" (p. 1). Seltzer-Kelly do indeed offer multiple perspectives from several coauthors that serve to outline various nodes in the plane of what teacher education is and what it might be. 
This said, after reading their work and having some time to process the ideas they present, my response falls into two overarching categories. On one hand, I applaud their questions of teacher education, collaboration, and collaborative inquiry. I share the authors' concerns about contemporary visions of schooling, processes of teacher education and mainstream notions of teaching. The positions they present here are certainly worthy of contemplation and the studies they present offer multiple means for considering the relationships between teachers and students, teacher educators and future teachers, and future teachers and their own aspirations.

On the other hand, once one works through the many layers the coauthors present, it is not clear that the suggestions they make add much to critical questions about teacher education from such fields as curriculum studies, complex collaborative methods of inquiry-both those that explicitly claim complexity and those that are reflexively multifaceted-or to the ways in which complexity might be utilized to further contemporary understandings of schooling.

This is because, as often happens, this article's greatest strength, its collaborative inquiry and polyvocality, is also ultimately its greatest detractor. As I outline below, Seltzer-Kelly et al.'s desire to speak to teacher education from multiple fields, studies, and perspectives, has the unintended consequence of missing key studies and discussions of teacher education as well as methodological possibilities from the very fields they traverse (e.g. critical qualitative reflexive methods, complexity in education research, curriculum studies, and ethnography). In light of this complication, it is not clear to this reader how the ideas presented here further the field of teacher education research or make clear the ways complexity can be applied to the study of human interactions.

Similarly, Seltzer-Kelly et al.'s collaboration and its possibilities do present one way in which complexity might further the ways in which research might be furthered through complexity science-in the working together from multiple perspectives. However, while the piece presents their polyvocality in a somewhat odd manner in which each person's perspective is presented, precisely how their collaboration functioned in practice is generally glossed over. Along similar lines, rather than stressing the dissonance within their perspectives, Seltzer-Kelly et al. elect to focus almost exclusively on "emergent points of convergence" (for an analysis of this concept see, Gershon \& Christodoulou, in press; Gershon, Peel \& Bilinovich, 2009). This lack of transparency also exists in the ways in which the coauthors utilize terminology and describe some of the scholarship they present. For example, where the claims regarding the "teacher-student interaction and expectancy effect" (pp. 7-11) are often explicitly outlined, although Kalinda's work is discussed, her methodology is largely absent.

The remainder of my review outlines these two overarching questions-how this piece further informs critical questions of mainstream teacher education or the ways in which it similarly furthers understandings of how complexity can be used to understanding schooling - in a more direct and empirical fashion. Before continuing, however, I wish to note that these questions are offered in the spirit of "complicated conversation" (Pinar, 2004), a construct that is common to the fields of autoethnography, 
complexity, curriculum studies, and quantitative methodology that the authors traverse in their article. As such, I look forward to their response to my thoughts about their work.

\section{Many Fields, Many Findings: The Trouble with Complex Constellations of Interpretation}

Working with others across fields and perspectives adds layers of questions about both the concepts and constructs coauthors present and the processes through which those ideas and ideals are presented (Gershon, 2009). Here, Seltzer-Kelly et al. seek to work from their multiple vantage points to redress what they wisely see as concerns in teacher education. It is therefore somewhat disappointing that they often collectively overlooked scholarship in the fields they cite on this very topic. For example, while the coauthors freely cite Dewey, Aoki, and Doll, curriculum theorists all, they have neglected the work of such scholars as Deborah Britzman $(1998,2003)$ whose well-respected scholarship lies at the very intersection of psychology, teaching, and curriculum that the coauthors address in this article (pp. 16-17). Also missing is any discussion of Pinar's (2004; Pinar, Reynolds, Slattery \& Taubman, 1995) autobiographical use of currere, a form of introspection and reflection that seems much more akin to the work done here than connections to the autoethnography (e.g. Behar, 1992) that the coauthors claim.

The same holds true for their discussion of the factory model in education (pp. $12+$ 13) as well as their talk about "reflexivity, complexity, and complicity" (pp. 13-15), and of "relationship, culture and care" (15-20). There is little mention of the large body of work on the "legacy of the factory model of education" (p. 12), from foundational scholarship in this area that spanned the late 1960's through the late 1970's (e.g. Rist, 1973; Willis, 1977) to more contemporary writing about its continuing residue, if not an explicit returning to this way of doing school (e.g. McNeil, 2000; Taubman, 2009).

This trend appears to resonate throughout their article. Examples include, but are not limited to, the presentation without reference to scholarship on the following concepts and constructs: reflexivity in/as methodology, previous uses of complexity in educational research or interpretive research, discussions of culture in education, or work that examines students expectations of schooling as they relate to sociocultural/economic precepts such as race, gender, class, and sexual orientation.

The net result of missing such scholarship is twofold. Not only have the points the authors raise been made elsewhere, but their claims about gaps in scholarship tend to fall short. For example, the coauthors write "Prior conceptions of reflective practice fall short to the degree that they position the teacher as an objective bystander, carrying out analysis and working from a position that is able to stand outside the system" (p. 14). , This statement misses a history of scholarship that interrupts mainstream notions of teaching and teacher preparation (e.g. Cochran-Smith \& Lytle, 1993; Ellsworth, 1989; Nofke \& Somekh, 2009). Likewise, their claim that "in a democracy, public schools can go beyond preparing students to deal with diversity; their very diversity creates the optimal conditions for developing each student's unique potential" (p. 24) is a 
foundational concept in such areas as urban education and queer education not to mention the scholarship of such scholars as W. E. B. DuBois, bell hooks, and Maxine Greene.

It is in these ways that what could have been a strength of this collaborative, their ability to bring multiple fields and perspectives to bear on an important issue, seems to have resulted in missing the complexity of the forest of scholarship for the trees of what each member brought to the table individually. As I briefly detail in the next section, a tendency not to define key terminology and a lack of transparency in process may well have contributed to this perception.

\section{Multiple Perspectives, Multiple Terms: Questions of Transparency in Definition and Process}

In the conclusion to their piece, the coauthors state that considering their "area of inquiry... from multiple perspectives can bring into focus a dizzying array of insights and ideas." However, they note that their focus is integral to complexity theory and thinking:

We freely admit, a complexity approach can confound all attempts to neatly encompass and describe the phenomenon under study, and that can be unsettling. As Suzanne observed during our panel presentation, bringing together research paradigms that are commonly perceived as being in competition with one another is at once anxietyprovoking and invigorating. (p. 30)

As a person who was not present at their panel, and one who appreciates emergent dissonance, it was not the multiplicity of Seltzer-Kelly et al.'s perspectives that I found difficult to conceptualize-such complexity is indeed commendable. Rather, it was their lack of clarity in presenting the connections between the nodes of experience in their topography and a similar absence of definition that often left me unsettled.

For example, the coauthors use "culture" to mean race (p. 20), the collective norms and values of a given group (p. 4, 21), an indicator of an era (p. 21), as an indicator of groups as separate from ethnicity, race, and, gender (p. 21), and the multiplicity of groups (p. 31). Seltzer-Kelly et al.'s talk about the lines between race, culture, ethnicity, and gender are similarly blurred due to a lack of definitional clarity, as in the following statement where "culture" appears to be a substitute for "race": "Negotiating culture in the classroom was something that Serina and Shannon-like too many new teachershad to discover on their own. Most of Serina's students, for example, were African American" (p. 18). While this use of the term culture is not necessarily uncommon in educational research (e.g. Gay, 2000), the complications of what culture means and contemporary questions about the existence of culture (e.g. Fox \& King, 2002), necessitates the definition and contextualization of such terms. The terms "democracy" and "classroom ecology" are also left largely undefined, two terms with a similar multiplicity of contested meanings.

In a similar fashion, there are instances in which one idea is utilized to describe another towards a third concept with little attention paid to the important differences 
between perspectives and ideas. This is the case when Gregory Bateson's work is interpreted through Mary Catherine Bateson's lens, as part of her requested therapy process by her psychologist - a journey through which Mary Catherine (2005) came "to view the family dynamic in terms of Gregory Bateson's thought: to see the pathology as a product of the interaction of systems, rather than as residing in any individual" (p. 5) - that is in turn offered through another layer of interpretation by Nora Bateson (2009) in her film "An Ecology of Mind." Although such layering can be interpreted as nested layers of meaning and a vision of self-similarity, it can also be seen as thrice-removed from the source document and its ideas, an interpretation of an interpretation of an idea.

While the coauthors' individual nodes of understanding are rendered largely explicit, Seltzer-Kelly et al.'s collaborative process is similarly undefined. Their article left me wondering how they aggregated and analyzed data across the coauthors' fields and findings, in what ways complexity science rather than the kinds of complex collaboration that are the hallmark of contemporary collaborative research practice informed their work, and which ideas were left on the editing floor in order to present this article comprised of "areas of connection and consensus-strands that appeared again and again across our writings and discussions" (p. 31).

It remains unclear to this reader, why, for instance, the coauthors elected to utilize processes of consensus, a consolidating of multiple perspectives, rather than dissensus, a construct that seems much more aligned with the chaotic, messy nature of complex ecologies (see for example, Gershon, Peel \& Bilinovich, 2009; Gershon \& Christodoulou, in press; Ranciére, 2010; Ziarek, 2001). Along similar lines, some kind of conceptual mapping of their process would have been quite helpful in allowing the reader to better appreciate the particular topography of their research ecology.

\section{Conclusion: Stuck Places and Possibilities}

When combined, the Seltzer-Kelly, et al.'s tendency to overlook work that lies within and along side the landscape of scholarship that their article traverses and an oftenpresent definitional and methodological lack of transparency combine to create an instance in which the richness of their ideas and perspectives are often muddled through polyphony rather than creating the rich tapestry of meaning that they envision. In addition, it is not clear from their work here either that their work reflects complexity science instead of being simply complex or how a complexity lens is advantageous over contemporary forms of (collaboration in) social science research that is similarly complex (cf. Gershon, 2009).

This remains something of a stuck place (Lather, 2007) not only for this article but also for complexity science in educational research as it is applied to interpreting human interactions in local and less local contexts. In sum, I am left wondering what was accomplished here that might not be conducted in as complex a fashion and more transparently through other research methodologies (cf. Erickson, 2006; Valli \& Chambliss, 2007). 
One possible answer lies in this article's strength and weakness, multiple voices used in tandem to examine a given idea, construct, or context. It is likely that SeltzerKelly et al. would be able to further others' more explicit use of complexity in/as research with this experience fresh in their minds. As I have noted here, a strong step in this direction could be greater transparency of process that more clearly underlines how such collaborations are indeed complex ecologies in a more literal, less figurative manner. In order to see the topography of their system, and to note the aspects that are self-similar or otherwise nested, it is important that the readers are shown rather than told how the trees make the forest. Such a move would also speak to ethical questions in contemporary research in which the researchers take on the translation of one context to another so that their acts of interpretation do not incidentally misrepresent those studied to others who were not present.

\section{References}

Bateson, M.C. (2005, August 28). Learning to teach, teaching to learn. The Philadelphia Inquirer. Retrieved from http://mcatherinebateson.blogspot.com/2005/09/learning-to-teach-teaching-tolearn.html

Bateson, N. (2009). An ecology of mind. [Film - Unedited version]. United States: Nora Bateson. (http://www.anecologyofmind.com/Page 2.html)

Behar, R. (1996). The vulnerable observer: Anthropology that breaks your heart. Boston: Beacon Press.

Britzman, D. P. (1998). Lost subjects, contested objects: Toward a psychoanalytic inquiry of learning. Albany, NY: State University of New York Press.

Brtizman, D. P. (2003). Practice makes practice: A critical study of learning to teach (revised ed). Albany, NY: State University of New York Press.

Cochran-Smith, M. \& Lytle, S. L. (1993). Inside/outside: Teacher research and knowledge. New York: Teachers College Press.

Davis, B. and Sumara, D. (2006). Complexity and education: Inquiries into learning, teaching and research. Mahwah, NJ: L. Erlbaum Associates.

Erickson, F. (2006). Studying side by side: Collaborative action ethnography in educational research. In G. Spindler \& L. Hammond (Eds.), Innovations in educational ethnography: Theory, methods and results. (pp. 235-258). Mahwah, NJ: L. Erlbaum Associates.

Ellsworth, E. (1989). Why doesn't this feel empowering? Working through the repressive myths of critical pedagogy. Harvard Educational Review, 59(3), 297-324.

Fox, R. G. \& King, B. J. (Eds.). (2002). Anthropology beyond culture. Oxford, UK: Berg.

Gay, G. (2000). Culturally responsive teaching: Theory, research, and practice. New York: Teachers College Press.

Gershon, W. S. (2008). Intent and expression: Complexity, ethnography, and lines of power in classrooms. Journal of the Canadian Association for Curriculum Studies, 6(1), 45-72.

Gershon, W. S. (Ed.). (2009). The collaborative turn: Working together in qualitative research. Rotterdam, NL: Sense Publications.

Gershon, W. S., Bilinovich, C., \& Peel, A. (2010). Race, social studies content, and pedagogy: Wrestling through discomfort together. Canadian Social Studies, 44(1), 29-37.

Gershon, W. S. \& Christodoulou, N. (in press). Dissensus in traveling without moving: Using videoconferencing to facilitate dialogue between preservice teachers in two nations. In T. C. Mason \& R. J. Helfenbein (Eds.), Ethics and international curriculum work: The challenges of culture and context. Charlotte, NC: Information Age Publishing.

Lather, P. (2007). Getting lost: Feminist efforts toward a double(d) science. Albany, NY: State University of New York Press. 
McNeil, L. (2000). Contradictions of school reform: Educational costs of standardized testing. New York: Routledge.

Noffke, S., \& Somekh, B. (Eds.). (2009). The handbook of educational action research. Thousand Oaks, CA: Sage Press.

Pinar, W. F. (2004). What is curriculum theory? New York: Routledge.

Pinar, W. F., Reynolds, R., Slattery, P. \& Taubman, P. (Eds.). (1995). Understanding curriculum: An introduction to the study of historical and contemporary curriculum discourses. New York: Peter Lang.

Ranciére, J. (2010). Dissensus: On politics and aesthetics. New York: Continuum.

Rist, R. (1973). The urban school: A factory for failure. Cambridge: Massachusetts Institute of Technology Press.

Seltzer-Kelly, D. L. et al. (2011). (Re)Imagining teacher education for conjoint democratic inquiry in complex classroom ecologies. Complicity

Taubman, P. M. (2009). Teaching by numbers: Deconstructing the discourse of standards and accountability in education. New York: Routledge.

Valli, L., \& Chambliss, M. (2007). Creating classroom cultures: One teacher, two lessons, and a highstakes test. Anthropology Education Quarterly, 38(1), 57-75.

Willis, P. (1977). Learning to labor: How working class kids get working class jobs. New York: Columbia University Press.

Ziarek, E. P. (2001). An ethics of dissensus: Postmodernity, feminism, and the politics of radical democracy. Stanford, CA: Stanford University.

\section{About the Author}

Walter S. Gershon is an Assistant Professor in the School of Teaching, Learning, and Curriculum Studies at Kent State University. His scholarly interests focus on the ways in which students make sense of their worlds and how those meanings are constructed through their senses, particularly in and through sound. This interest tends to center on questions about the relationship between curriculum and students, the ways in which sociocultural precepts inform this relationship, and the qualitative research methodologies utilized to study educational actors' sensemaking. Walter is the author of The Collaborative Turn: Working Together in Qualitative Research (Sense Publishing, 2009) and is guest editor of a forthcoming special issue of the Journal of Curriculum Theorizing that explores the intersection of curriculum and the senses. Prior to his time in higher education, Walter taught in urban schools in the United States and in rural and urban contexts in Japan.

(C) Copyright 2011. The author, Walter S. Gershon, assigns to the University of Alberta and other educational and non-profit institutions a non-exclusive license to use this document for personal use and in courses of instruction provided that the article is used in full and this copyright statement is reproduced. The author also grants a non-exclusive license to the University of Alberta to publish this document in full on the World Wide Web, and for the document to be published on mirrors on the World Wide Web. Any other usage is prohibited without the express permission of the authors. 